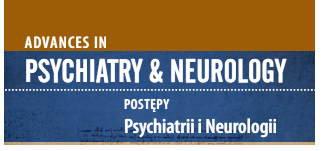

Correspondence to/

Adres do korespondencji:

Bartosz Osuch

Zakład Neurochemii

Instytut Psychiatrii i Neurologii

Warszawa, Polska

e-mail: bartosz.osuch@op.pl

Submitted/Otrzymano: 11.01.2019

Accepted/Przyjęto do druku: 05.03.2019

\section{THE ROLE OF MITOPHAGY IN SELECTED NEURODEGENERATIVE DISEASES}

\section{ROLA MITOFAGII W WYBRANYCH CHOROBACH NEURODEGENERACYJNYCH}

\author{
Bartosz Osuch', Teresa Kucharska', Natalia Chmielewska', \\ Piotr Maciejak' 1,2, Janusz Szyndler',2, Adam Płaźnik'
}

'Department of Neurochemistry, Instytute of Psychiatry and Neurology, Warsaw, Poland.

${ }^{2}$ Department of Experimental and Clinical Pharmacology, Medical University of Warsaw, Warsaw, Poland

'Zakład Neurochemii, Instytut Psychiatrii i Neurologii, Warszawa, Polska ${ }^{2}$ Katedra i Zakład Farmakologii Doświadczalnej i Klinicznej, Warszawski Uniwersytet Medyczny, Warszawa, Polska

\begin{abstract}
Purpose: Mitophagy is a type of selective autophagy, associated with degradation of inefficient mitochondria. The modulation of mitophagy seems to be one of the most important solutions for key factors in the maintenance of neuronal cell homeostasis. This paper overviews the role of mitochondria and mitophagy in the etiology of the most common age-related neurodegenerative diseases, i.e. Alzheimer's disease (AD) and Parkinson's disease (PD).

Views: In recent years, the role of mitophagy in neurodegenerative diseases has been given more attention. It has been shown that disturbed mitophagy and mitochondrial dysfunction in neurons may contribute to the cell death. In AD and PD, a number of abnormalities related to the expression and function of proteins involved in the process have been revealed. Because mitochondrial dysfunction plays a role in the origin/etiology of those diseases, possible therapeutic strategies aiming to improve quality control systems of mitochondria are also presented. Nowadays, these are mainly strategies improving the energy efficiency and facilitating induction of mitophagy.

Conclusions: Recent reports suggest that abnormal function of proteins involved in mitophagy may be an important etiological factor in neurodegenerative diseases. Furthermore, these findings may become the basis for the development of more effective therapies preventing or alleviating the disease symptoms.
\end{abstract}

Key words: mitophagy, mitochondria, Alzheimer's disease, Parkinson's disease.

\title{
Streszczenie
}

Cel: Mitofagia jest rodzajem selektywnej autofagii, podczas której degradacji ulegają mało wydajne mitochondria. Modulacja procesu mitofagii wydaje się obecnie jednym z najważniejszych rozwiązań umożliwiających utrzymanie homeostazy komórek nerwowych. Celem niniejszej pracy jest podsumowanie istniejącej wiedzy dotyczącej roli mitochondriów oraz procesu mitofagii w etiologii najbardziej rozpowszechnionych chorób neurodegeneracyjnych związanych z wiekiem, tj. choroby Alzheimera $(\mathrm{AD})$ i choroby Parkinsona (PD).

Poglądy: W ostatnich latach obserwuje się wzrost zainteresowania rolą mechanizmu mitofagii w powstawaniu chorób neurodegeneracyjnych. Wykazano, że zaburzona funkcja mitochondriów i utrata zdolności do mitofagii w komórkach nerwowych może przyczyniać się do ich śmierci. W AD i PD zaobserwowano szereg nieprawidłowości związanych z ekspresją oraz funkcją białek zaangażowanych w ten proces. Ze względu na powiązanie zaburzeń funkcji mitochondrialnych z omawianymi chorobami w niniejszej pracy przedstawiono także możliwe strategie terapeutyczne ukierunkowane na poprawę wewnątrzkomórkowych systemów kontroli jakości tych organelli. Obecnie są to przede wszystkim strategie poprawiające wydajność energetyczną komórek nerwowych i rozwiązania umożliwiające kontrolowane indukowanie procesu mitofagii.

Wnioski: Najnowsze badania wskazują, że nieprawidłowe funkcjonowanie białek zaangażowanych w proces mitofagii może stanowić ważny czynnik etiologiczny chorób neurodegeneracyjnych. Wyniki tych badań mogłyby stać się podstawą do opracowania skuteczniejszych terapii zapobiegających wystąpieniu objawów wspomnianych chorób bądź łagodzących ich przebieg.

Słowa kluczowe: mitofagia, mitochondria, choroba Alzheimera, choroba Parkinsona. 


\section{INTRODUCTION}

Ageing is one of the most important risk factors for common neurodegenerative disorders, such as Alzheimer's disease (AD) and Parkinson's disease (PD). With the increase in life expectancy, new treatments are being intensively searched for. Although general mechanisms behind age-related neurodegeneration have been identified, the complex processes responsible for its development are still not fully understood, and current pharmacotherapy is still based on symptomatic treatment.

The main pathomechanism of these neurodegenerative diseases is the aggregation of abnormally folded proteins and the associated loss of specific nerve cell populations. In $\mathrm{AD}$, the changes affect areas of the brain that are key to learning and memory processes, i.e. hippocampus, rhinencephalon and frontal cortex $[1,2]$. In PD, dopaminergic neurons in substantia nigra of the midbrain are lost [3]. Maintaining the integrity of neuronal networks is dependent on factors involved in the removal of nerve tissue waste products. Among them, autophagy - an evolutionary conservative intracellular mechanism based on the elimination of macromolecular components of cytoplasm, especially proteins with a long half-life and whole organelles - has a great application potential in controlling the processes of neurodegeneration [4-11]. Autophagy is non-selective, when a part of the cytoplasm is digested and the balance between the size and composition of the cytoplasm is being kept. However, this process can be very specific and lead to the degradation of specific structures, such as protein aggregates, cell organelles, as well as bacteria and viruses. A type of selective autophagy important for cell homeostasis is mitophagy - a process of degrading damaged and inefficient mitochondria $[12,13]$. Neurons as cells showing a high energy demand dependent on mitochondrial metabolism are particularly sensitive to mitochondrial dysfunction [14-18]. Besides, neurons do not have the ability to proliferate, therefore an efficient system is needed to eliminate damaged mitochondria, which may be a source of reactive oxygen species (ROS) or a factor triggering apoptosis [19].

In recent years, the role of mitophagy in neurodegenerative diseases has been given more attention. It has been shown that disturbed mitophagy and mitochondrial dysfunction in neurons may contribute to the cell death. In $\mathrm{AD}$ and $\mathrm{PD}$, a number of abnormalities related to the expression and function of proteins involved in the process have been revealed. Here we review data showing that abnormal function of proteins involved in mitophagy may be an important etiological factor in neurodegenerative diseases. Furthermore, these findings may become the basis for the development of more effective therapies preventing or alleviating the symptoms.

\section{THE MOLECULAR MECHANISM OF MITOPHAGY}

Over the last decade, significant progress has been made in the study of molecular mechanisms underlying mitophagy - a process in which autophagosome engulfs damaged mitochondria and directs them towards lysosomal degradation. This research has helped to identify the proteins involved and to understand their role in physiological and pathological conditions. There are two known mechanisms of mitophagy: dependent on and independent of ubiquitin. Ubiquitin is a low molecular weight protein which marks proteins intended for degradation. The addition of ubiquitin molecules to proteins is called ubiquitination. This paper focuses primarily on the ubiquitin-dependent mitophagy, since disturbances in the function of proteins involved in the process have a significant impact on the development of both diseases.

PTEN-induced kinase 1 (PINK1) is a serine-threonine kinase located on the outer mitochondrial membrane (OMM). PINK1 together with the cytoplasmic E3 ubiquitin ligase (Parkin) are important factors involved in the removal of dysfunctional mitochondria on the way of by means of ubiquitin-dependent mitophagy [20].

PINK1 occurs in small amounts in properly functioning mitochondria. PINK1 is transported via TOM/ TIM membrane translocases from the outer to the inner mitochondrial membrane (IMM), and is cut by mitochondrial proteases. The remaining part of PINK1 is released into the cytoplasm where it undergoes proteolytic degradation (Figure IA) [21-23]. In dysfunctional mitochondria with a loss of membrane potential, PINK1 degradation is inhibited. It then binds permanently with the TOM subunit of the TOM/TIM complex, which leads to its accumulation in the OMM and initiates mitophagy [23]. The inhibition of PINK1 degradation causes the recruitment of cytoplasmic Parkin and its connection to the mitochondrion with a lost membrane potential $[24,25]$.

Linked to the mitochondrial surface and activated by PINK1, parkin initiates the ubiquitination of proteins of the OMM, including Mitofusin 1 and Mitofusin 2 (Mfn1 and Mfn2), mitochondrial Rho GTPase 1 (Miro1), voltage-dependent anion-selective channel protein (VDAC1). Mfn1 and Mfn2 preserve mitochondria connections [26]. In a cell, mitochondria connect to each other, forming a spatial and branched network. Probably, such an organisation contributes to the intensification of energy production and facilitates maintaining homeostasis in response to stress conditions [27]. Depending on the needs, the network can be modified by connecting or disconnecting individual mitochondria. Decreased activity of Mfn1 and Mfn2 proteins causes isolation of a dysfunctional mitochondrion from the mitochondrial network [26]. Another substrate for parkin is Mirol protein, 
which binds mitochondria to the microtubules and thus provides for each mitochondrion a possibility of movement within the network. Inhibition of Miro1 facilitates isolation and immobilises mitochondrion by disconnecting it from the microtubule $[26,28]$. Another protein involved in mitochondrial division is dynamin-related protein 1 (Drp1). PINK1 and parkin can activate Drp1, which results in disconnection of a mitochondrion from the network $[29,30]$. In addition, to the proteins of the OMM, polyubiquitin chains are attached which recruit proteins binding microtubule-associated proteins 1A/1B light chain 3 (LC3) present on the surface of a maturing autophagosome. When a damaged mitochondrion is attached to an autophagosome, the autophagosome membrane elongates and closes the mitochondrion inside for the lysis (Figure IB) [31].

The inhibitors of ubiquitin-dependent mitophagy are deubiquitinating enzymes, including USP15, USP30, and USP35, pivotal to maintaining balance between ubiquitination and deubiquitination. Excessive expression of these enzymes may inhibit the mitophagy through increased removal of polyubiquitin chains [32].

\section{MITOCHONDRIAL DISORDERS IN ALZHEIMER'S AND PARKINSON'S DISEASES}

Neurodegenerative diseases have different clinical symptoms. However, it is now believed that similar mechanisms leading to neuronal degeneration are responsible for their occurrence. In the nervous tissue of patients with $\mathrm{AD}$ and PD, accumulation of neurotoxic and enzyme resistant aggregates is observed. Furthermore, dysfunctional mitochondria have also been found. This indicates faulty mitochondrial function and a diminished ability to mitophagy as a new cause of neurodegeneration [17, 33-36].

\section{Alzheimer's disease}

The neuropathological symptoms of $\mathrm{AD}$ show extracellular accumulation of $\beta$-amyloid $(A \beta)$ plates and formation of intracellular neurofibrillary tangles, which are aggregates of hyperphosphated tau protein $[17,33,34]$. An important role in the pathogenesis of $\mathrm{AD}$ is being currently attributed to the interaction of $A \beta$ with mitochon-

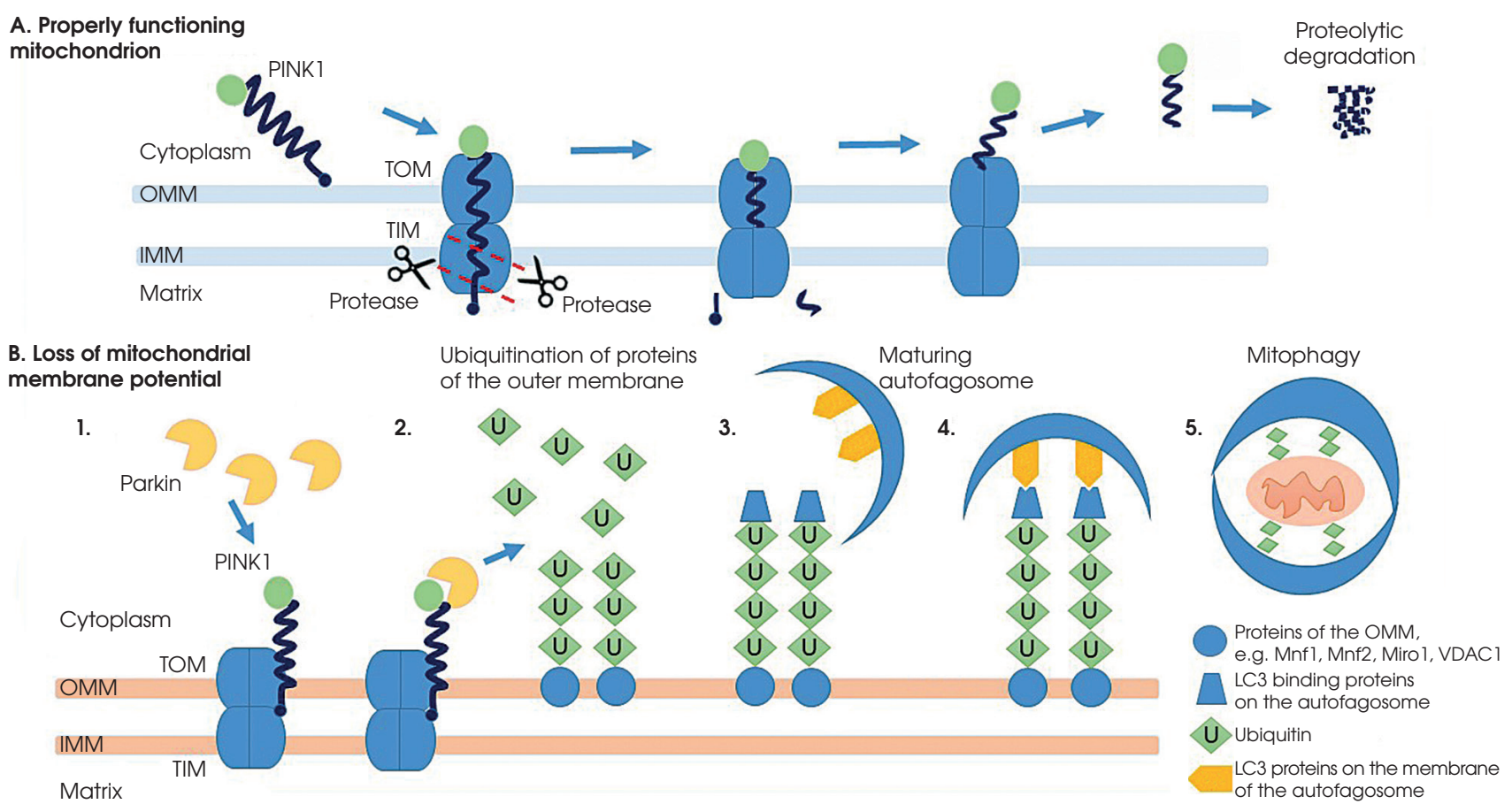

Figure I. The mechanism of ubiquitin-dependent mitophagy. A. In properly functioning mitochondria, a PINK 1 is transported through the TOM/TIM complex from the OMM to the IMM, where it is cut by mitochondrial proteases. Then the remaining part of the PINK 1 is released into the cytoplasm and undergoes proteolytic degradation. B. As a result of the loss of membrane potential, the transport of PINK 1 by the TOM/TIM complex is inhibited. 1. PINK1 connects to the TOM subunit of the TOM/TIM complex and accumulates on the external surface of the mitochondria. The presence of PINK 1 recruits cytoplasmic Parkin and leads to its activation. 2. Activated by PINK1 Parkin initiates the process of ubiquitination of proteins of the OMM, e.g. Mnfl, Mnf2, Mirol, VDAC1. As a result, polyubiquitin chains are attached to mitochondrial proteins. 3. Polyubiquitin chains are recognised by proteins that have the ability to bind to the LC3 proteins present on the autophagosome membrane. 4. The dysfunctional mitochondrion is attached to the membrane of the maturing autophagosome. 5. The autophagosome membrane lengthens and closes the mitochondrion for lysis 
drial matrix proteins, dynamics and distribution of mitochondria in nerve cells, and mitochondrial respiratory chain abnormalities [37-40]. Recent reports also point to the disturbance in the expression of key proteins associated in mitophagy: PINK1 and parkin [41].

It has been revealed that in $\mathrm{AD}, \mathrm{A} \beta$ and phosphorylated tau protein interact with the Drp1 protein, causing excessive mitochondrial fragmentation [40]. Intensified and prolonged fragmentation causes a decrease in mitochondrial membrane's internal potential and increased permeability disrupting proper function of the electron transport chain [42]. The consequence of abnormal functioning of the respiratory chain complex III and IV is a decrease in ATP production, an increase in oxidative stress, and disruption of calcium homeostasis. Increased $\mathrm{Ca}^{2+}$ concentration in neurons may affect both phosphorylation of tau protein and enzymatic treatment of $\beta$-amyloid precursor protein (APP), leading to the accumulation of $A \beta$ [43]. It was also shown that $A \beta$ molecules can form pores permeable for $\mathrm{Ca}^{2+}$ in the cell membrane and additionally disturb calcium homeostasis, contributing to the formation of free oxygen radicals. Oxidative stress caused by the accumulation of $A \beta$ and calcium excess may contribute to the mitochondrial dysfunction [44]. Early accumulation of structurally abnormal mitochondria was observed in $\mathrm{AD}$ patients and a similar change was observed in $\mathrm{AD}$ animal models [43, 44].

Although processes preceding the clinical manifestation of $\mathrm{AD}$ are being increasingly understood, signal pathways inducing mitophagy in the neurons of patients are still unknown. Recent reports suggest that neurons affected by AD, at first stages, show a strong induction of mitophagy through increased recruitment of parkin to the damaged mitochondria. As the disease progresses, the intensified process of mitophagy leads to a reduction in the cytosolic parkin, which results in accumulation of dysfunctional mitochondria [45]. In the neurons of $\mathrm{AD}$ patients with established clinical symptoms, mitophagy impairment associated with a decreased park level and insufficient number of autophagosomes led to accumulation of depolarised mitochondria and PINK1 [41]. Additionally, overexpression of parkin in cell line and mouse $\mathrm{AD}$ model caused increased removal of defective mitochondria by intensified synthesis of autophagosomes. This resulted in the recovery of mitochondrial membrane potential and decreased PINK1 accumulation [41, 46].

\section{Parkinson's disease}

In PD, the presence of neurons with modified $\alpha$-synuclein protein inclusions in the cytoplasm, called Lewy's bodies, is characteristic [33]. Although the majority of patients are diagnosed with an idiopathic form of PD, the less common family form of this condition has helped to identify genes that are a risk factor. Predominantly, five genes mutations involved in PD development are described.
These genes code $\alpha$-synuclein, parkin, PINK1, protein DJ-1 and kinase $2[47,48]$. In the pathogenesis of PD, besides a-synuclein, an important role is also played by parkin and PINK1, which are key factors involved in the signal pathway leading to marking and absorption of dysfunctional mitochondria in the mitophagy $[49,50]$. The clinical phenotype of PD in patients with those genes mutations is similar to the idiopathic form of the disease. The hereditary form of PD is characterised by earlier manifestation, especially in parkin mutations. Neuropathologically, there are no significant differences [51].

Decreased activity of NADH dehydrogenase, an enzyme present in the IMM of mitochondria, which is a complex of respiratory chain I, is also associated with PD [52]. Mitochondrial toxins, which are inhibitors of this complex, are used in animal models of the disease. A decrease in electron transport chain activity results in an imbalance of calcium homeostasis in the brain and changes in the function of calcium channels (VDCC) type L. It may cause easier end frequent opening of the channel and excessive influx of $\mathrm{Ca}^{2+}$ into the neurons, contributing to the formation of free oxygen radicals $[53,54]$. Oxidative stress induced by damaged mitochondria causes degeneration of substantia nigra and manifestation of symptoms in experimental animals [55-57]. Interestingly, cells isolated from the brain of mice with PINK-1 knock out gene also showed limited capacity of calcium buffering and increased susceptibility to inflammation-induced oxidative stress [58].

Mitochondrial stress caused by reduced respiratory chain activity causes changes in the organisation of the mitochondrial network. In the rat line of dopaminergic neurons, it has been shown that inhibition of complex I of electron transport chain caused by 1-methyl-4-phenylpridinium neurotoxin (MPP+) and oxidative stress causes fragmentation of mitochondrial network [59]. Similar changes were observed after administration of the complex inhibitor I - rotenone [60, 61]. Intensified division of mitochondria may lead to a decrease in the membrane potential. In that condition, PINK1 does not degrade and accumulates in the OMM, thus initiating the process of mitophagy depending on ubiquitin. Reduced membrane potential, increased $\mathrm{Ca}^{2+}$ levels, and excess of ROS in mitochondria of nerve cells were also found in animal knock out of PINK1 and parkin genes [62-64].

\section{IMPROVEMENT OF MITOCHONDRIAL FUNCTION IN ALZHEIMER'S DISEASE AND PARKINSON'S DISEASE AS A THERAPEUTIC TARGET}

Because mitochondrial dysfunctions are believed to be associated with the two neurodegenerative diseases, in recent years the search for methods to improve mitochondrial functions has been given a lot of interest. Nowadays, 
the best candidates are drugs supporting mitochondrial mechanisms related to maintaining energy efficiency. These are natural antioxidants, given that oxidative stress plays an important role in the pathophysiology of neurodegenerative diseases. Mitochondria are not only the main production site of ATP, but also an important modulator of oxidative potential in the cell. These organelles constantly generate ROS as a by-product of oxygen metabolism. Mitochondrial DNA mutations (mtDNAs) accumulate in nerve cells with aging. It may lead to changes in the oxidative phosphorylation, the expression of antioxidant enzymes, and an overproduction of ROS [65]. Excessive accumulation of ROS weakens the bioenergetic function of mitochondria, leading to numerous mutations in nuclear and mitochondrial DNA, which decreases the tricarboxylic acid cycle activity and disrupts the respiratory chain function [65]. Therefore, strategies for induction of the mitophagy process seem to be the key to treatment and prevention of neurodegenerative diseases. The solutions described below, allow to partially restore and increase the intensity of endogenous quality control mechanisms.

Lycopene - a carotenoid compound naturally occurring primarily in tomatoes and other red fruits, has a strong ability to remove free radicals. It is suggested that lycopene has a therapeutic potential for neurodegenerative diseases. The beneficial effect of lycopene supplementation has been shown in the PD rat model, where the oxidative stress caused by rotenone was reduced by restoring the level of endogenous antioxidants (glutathione and peroxide dismutase) and by reactivation of the respiratory complex I in mitochondria [57]. Another promising antioxidant is resveratrol - polyphenol naturally occurring mainly in dark grape varieties. Resveratrol not only reduces ROS, but also increases the APP protein degradation, improves the clearance of the neurotoxic protein $A \beta$ and reduces its aggregation [66-68]. It was also found to be a potential inhibitor of proapoptic factors, such as the Bax protein, which takes part in the formation of channels increasing the permeability of the outer mitochondrial membrane [68, 69]. Neuroprotective action of resveratrol is probably also associated with stimulation of sirtuin synthesis, which reduces ROS levels [70]. However, numerous studies have shown that the use of resveratrol may be limited due to low bioavailability and some effort has been made to improve its properties through structural modifications. In vitro studies have shown that methylated and butylated resveratrol derivatives have better neuroprotective and anti-inflammatory properties [71].

Another organic chemical with neuroprotective effects is creatine, which after being absorbed into the brain and skeletal muscles is converted into phosphocreatine (PCr) by cytosolic and mitochondrial creatine kinase. $\mathrm{PCr}$ is the buffering factor for ATP in tissues with high energy demand, such as skeletal muscles and the brain [72]. Numerous independent studies have shown that creatine blocks the death of neurons and increases neuron vitality in experimental models of animal neurodegenerative disorders [73]. The effectiveness of creatine in treating PD patients has not been demonstrated by a long-term exploratory study conducted by the National Institutes of Health (NIH). Based on the Unified Parkinson's Disease Rating (UPDRS), no significant differences were found between patients receiving creatine monohydrate and those receiving placebo [74]. However, due to promising pre-clinical studies, creatinine could be used in combination therapy. Polytherapy of creatine with ubiquinone (coenzyme Q10) shows additive neuroprotective effect in animal PD models [75]. Ubiquinone is an essential biological cofactor of the electron transport chain, which removes free oxygen radicals in the IMM by interacting with $\alpha$-tocopherol. Coenzyme Q10 also showed neuroprotective effects in several models of neurodegenerative disorders in vitro and in vivo $[72,76]$.

The mitophagy seems to be a key pathway in quality control of these organelles. Unfortunately, compounds currently used to induce mitophagy in vitro are very toxic and non-selective. Significant research has led to the development of a new potential inductor of mitophagy - PMI (P62-mediated mitophagy inducer). PMI increases expression and signalling of autophagic adaptive molecule P62/SQSTM1 in mitochondria, activating mitophagy independently of PINK1/parkin pathway, and thus does not cause loss of mitochondrial membrane potential and does not affect mitochondrial network. Thus, the action of PMI does not include non-specific effects associated with a sudden decrease in the membrane potential, characteristic of compounds routinely used to induce mitophagy in vitro, and may be a prototype pharmacological tool for the exploration of molecular mechanisms of this process [77].

\section{CONCLUSIONS}

The improvement of mitochondria quality control mechanisms, including mitophagy, seems to be one of the most promising therapeutic interventions in PD and $\mathrm{AD}$. The aim is difficult to achieve because the processes responsible for the proper functioning of mitochondria are under control of many complexes and not fully understood cellular mechanisms. Current symptomatic therapies do not allow to solve the problem of progressive neurodegeneration and do not allow to completely abolish the symptoms of the late stage. For this reason, most of the research focuses on the search for neuroprotective, regenerative and replacement therapies. Nowadays, there is no unequivocally effective therapeutic approach able to control the dynamics of mitochondria and the mitophagy. Explaining the interrelation of many molecular mechanisms, metabolic and biochemical processes related to mitochondrial functions, and finding factors activating these processes will facilitate the search for new, effective methods of treating these diseases. 
The role of mitophagy in selected neurodegenerative diseases

Rola mitofagii w wybranych chorobach neurodegeneracyjnych

\section{Conflict of interest/Konflikt interesu}

Absent./Nie występuje.

\section{Financial support/Finansowanie}

This study was supported by Grant No. UMO-2016/21/B/NZ7/02066 from the National Science Centre, Poland

\section{References/Piśmiennictwo}

1. Soelke DJ. Alzheimer disease: mechanistic understanding predicts novel therapies. Ann Intern Med 2004; 140: 627-638.

2. Uzun S, Kozumplik O, Folnegović-Smalc V. Alzhemer's dementia: current data review. Coll Antropol 2011; 35 : 1333-1337.

3. Dauer W, Przedborski S. Parkinson's disease: mechanisms and models. Neuron 2003; 39: 889-909.

4. Tekashige K, Baba M, Tsuboi S, Noda T, Ohsumi Y. Autophagy in yeast demonstrated with proteinase-deficient mutants and conditions for its induction. J Cell Biol 1992; 119: 301-311.

5. Tsukada M, Ohsumi Y. Isolation and characterization of autophagy-defective mutants of Saccharomyces cerevisiae. FEBS Lett 1993; 333: 169-174.

6. Baba M, Takeshige K, Baba N, Ohsumi Y. Ultrastructural analysis of the autophagic process in yeast: detection of autophagosomes and their characterization. J Cell Biol 1994; 124: 903-913.

7. Mizushima N, Noda T, Yoshimori T, Tanaka Y, Ishii T, George M.D, Klionsky DJ, Ohsumi M, Ohsumi Y. A protein conjugation system essential for autophagy. Nature 1998; 395: 395-398.

8. Ohsumi Y. Molecular dissection of autophagy: two ubiquitin like systems. Nat Rev Moll Cell Biol 2001; 2: 211-216.

9. Adachi A, Koizumi M, Oshumi Y. Autophagy induction undercarbon starvation conditions is negatively regulated by carbon catabolite repression. J Biol Chem 2017; 292: 19905-19918.

10. Guo F, Liu X, Cai H, Le W. Autophagy in neurodegenerative diseases: pathogenesis and therapy. Brain Pathol 2018; 28: 3-13.

11. Rodolfo C, Campello S, Cecconi F. Mitophagy in neurodegenerative diseases. Neurochem Int 2018; 117: 156-166.

12. Ding WX, Yin XM. Mitophagy: mechanisms, pathophysiological roles, and analysis. Biol Chem 2012; 393: 547-564.

13. Springer MZ, Macleod KF. In Brief: Mitophagy: mechanisms and role in human disease. J Pathol 2016; 240: 253-255.

14. Kann O, Kovacs R. Mitochondria and neuronal activity. Am J Physiol Cell Physiol 2007; 292: 641-657.

15. Brini M, Cali T, Ottolini D, Carafoli E. Neuronal calcium signaling: function and dysfunction. Cell Mol Life Sci 2014; 71: 2787-2814.

16. Depp C, Bas-Orth C, Schroeder L, Hellwig A, Bading H. Synaptic activity protects neurons against calciummediated oxidation and contraction of mitochondria during excitotoxicity. Antioxid Redox Signal 2017; 29: 1109-1124.

17. Kerr JS, Adriaanse BA, Greig NH, Mattson MP, Cader MZ, Bohr VA, Fang EF. Mitophagy and Alzheimer's disease: cellular and molecular mechanisms. Trends Neurosci 2017; 40: 151-166.

18. Silzer TK, Phillips NR. Etiology of type 2 diabetes and Alzheimer's disease: exploring the mitochondria. Mitochondrion 2018; 43: 16-24.

19. Lionaki E, Markaki M, Palikaras K, Tavernarakis N. Mitochondria, autophagy and age-associated neurodegenerative diseases: New insights into a complex interplay. Biochim Biophys Acta 2015; 1847: 1412-1423.

20. Palikaras K, Linoaki E, Tacernarakis N. Mechanisms of mitophagy in cellular homeostasis, physiology and pathology. Nat Cell Biol 2018; 20: 1013-1022.

21. Kubli DA, Gustafsson AB. Mitochondria and Mitophagy: The Yin and Yang of Cell Death Control. Circ Res 2012; 111: 1208-1221.

22, Sekine S, Youle RJ. PINK1 import regulation; a fine system to convey mitochondrial stress to the cytosol. BMC Biol 2018; 16: 2.

23. Harper JW, Ordureau A, Heo JM. Building and decoding ubiquitin chains for mitophagy. Nat Rev Mol Cell Biol 2018; 19: 93-108.

24. Shiba-Fukushima K, Imai Y, Yoshida S, Ishihama Y, Kanao T, Sato S, Hattori N. PINK1-mediated phosphorylation of the Parkin ubiquitin-like domain primes mitochondrial translocation of Parkin and regulates mitophagy. Sci Rep 2012; 2: 1002.

25. Kazlauskaite A, Kondapalli C, Gourlay R, Campbell DG, Ritorto MS, Hofmann K, et al. Parkin is activated by PINK1-dependent phosphorylation of ubiquitin at Ser65. Biochem J 2014; 460: 127-139.

26. Tanaka A, Cleland MM, Xu S, Narendra DP, Suen DF, Karbowski M, Youle RJ. Proteasome and p97 mediate mitophagy and degradation of mitofusins induced by Parkin. J Cell Biol 2010; 191: 1367-1380.

27. Hoitzing H, Johnston IG, Jones NS. What is the function of mitochondrial networks? A theoretical assessment of hypotheses and proposal for future research. Bioessays 2015; 37: 687-700.

28. Yoo SM, Jung YK. A Molecular Approach to Mitophagy and Mitochondrial Dynamics Mol Cells 2018; 41: 18-26.

29. Pryde KR, Smith HL, Chau KY, Schapira AH. PINK1 disables the anti-fission machinery to segregate damaged mitochondria for mitophagy. J. Cell Biol 2016; 213: 163-171.

30. Buhlman L, Damiano M, Bertolin G, Ferrando-Miguel R, Lombès A, Brice A, Corti O. Functional interplay between Parkin and Drp1 in mitochondrial fission and clearance. Biochim Biophys Acta 2014; 1843: 2012-2026. 
31. Wild P, McEwan DG, Dikic I. The LC3 interactome at a glance. J Cell Sci 2014; 127: 3-9.

32. Bingol B, Tea JS, Phu L, Reichelt M, Bakalarski CE, Song Q, et al. The mitochondrial deubiquitinase USP30 opposes parkin-mediated mitophagy. Nature 2014; 510: 370-375.

33. Ramanan VK, Saykin AJ. Pathways to neurodegeneration: mechanistic insights from GWAS in Alzheimer's disease, Parkinson's disease, and related disorders. Am J Neurodegener Dis 2013; 2: 145-175.

34. Selkoe DJ, Hardy J. The amyloid hypothesis of Alzheimer's disease at 25 years. EMBO Mol Med 2016; 8: 595-608.

35. Martinez-Vicente M. Neuronal Mitophagy in Neurodegenerative Diseases. Frontiers in Molecular Neuroscience 2017; 10: 64 .

36. Kim M, Ho A, Hee Lee J. Autophagy and Human Neurodegenerative Diseases - A Fly's Perspective. Int J Mol Sci 2017; 18; doi: 10.3390/ijms18071596.

37. Du H, Guo L, Fang F, Chen D, Sosunov AA, McKhann GM, et al. Cyclophilin D deficiency attenuates mitochondrial and neuronal perturbation and ameliorates learning and memory in Alzheimer's disease. Nat Med 2008; 14: 1097-1105.

38. Manczak M, Calkins MJ, Reddy PH. Impaired mitochondrial dynamics and abnormal interaction of amyloid beta with mitochondrial protein Drp1 in neurons from patients with Alzheimer's disease: implications for neuronal damage. Hum Mol Genet 2011; 20: 2495-2509.

39. Reddy PH, Tripathi R, Troung Q, Tirumala K, Reddy TP, Anekonda V, et al. Abnormal mitochondrial dynamics and synaptic degeneration as early events in Alzheimer's disease: implications to mitochondria-targeted antioxidant therapeutics. Biochim Biophys Acta 2012; 1822: 639-649.

40. Kandimalla R, Reddy PH. Multiple Faces of Dynamin-related Protein 1 and Its Role in Alzheimer's Disease Pathogenesis. Biochim Biophys Acta 2016; 1862: 814-828.

41. Martin-Maestro P, Gargini R, Perry G, Avila J, Garcia-Escudero V. PARK2 enhancement is able to compensate mitophagy alterations found in sporadic Alzheimer's disease. Hum Mol Genet 2016; 25: 792-806.

42. Wang X, Su B, Liu W, He X, Gao Y, Castellani RJ, et al. DLP1-dependent mitochondrial fragmentation mediates 1-methyl-4-phenylpyridinium toxicity in neurons: implications for Parkinson's disease. Aging Cell 2011; 10: 807823.

43. Wojda U, Salinska E, Kuznicki J. Calcium ions in neuronal degeneration. IUBMB Life 2008; 60: 575-590.

44. Goiran T, Duplan E, Chami M, Bourgeois A, El Manaa W, Rouland L, et al. $\beta$-Amyloid Precursor Protein Intracellular Domain Controls Mitochondrial Function by Modulating Phosphatase and Tensin Homolog-Induced Kinase 1 Transcription in Cells and in Alheimer Mice Models. Biological Psychiatry 2018; 83: 416-427.

45. Ye X, Sun X, Starovoytov V, Cai Q. Parkin-mediated mitophagy in mutant hAPP neurons and Alzheimer's disease patient brains. Hum Mol Genet 2015; 24: 2938-2951.

46. Khandelwal PJ, Herman AL, Hoe HS, Rebeck GW, Moussa CE. Parkin mediates beclin-dependent autophagic clearance of defective mitochondria and ubiquitinated Abeta in AD models. Hum Mol Genet 2011; 20: 20912102.

47. Kitada T, Asakawa S, Hattori N, Matsumine H, Yamamura Y, Minoshima S, et al. Mutations in the parkin gene cause autosomal recessive juvenile parkinsonism. Nature 1998; 392: 605-608.

48. Mata IF, Lockhart PJ, Farrer MJ. Parkin genetics: one model for Parkinson's disease. Hum Mol Genet 2004; 13 : 127-133.

49. Durcan TM, Fon EA. The three 'P's of mitophagy: PARKIN, PINK1, and post-translational modifications. Genes Dev 2015; 29: 989-999.

50. Pickrell AM, Youle RJ. The roles of PINK1, parkin, and mitochondrial fidelity in Parkinson's disease. Neuron 2015; 85: 257-273.

51. Matsumine H, Saito M, Shimoda-Matsubayashi S, Tanaka H, Ishikawa A, Nakagawa-Hattori Y, et al. Localization of a gene for an autosomal recessive form of juvenile Parkinsonism to chromosome 6q25.2-27. Am J Hum Genet 1997; 60: 588-596.

52. Correia SC, Carvalho C, Cardoso S, Santos RX, Santos MS, Oliveira CR, et al. Mitochondrial Preconditioning: A Potential Neuroprotective Strategy. Front Aging Neurosci 2010; 2: 138.

53. Berridge MJ, Bootman MD, Roderick HL. Calcium signalling: dynamics, homeostasis and remodeling. Nat Rev Mol Cell Biol 2003; 4: 517-529.

54. Hurley MJ, Dexter DT. Voltage-gated calcium channels and Parkinson's disease. Pharmacol Ther 2012; 133: 324-333.

55. Sherer TB, Betarbet T, Testa CM, Seo BB, Richardson JR, Kim JH, et al. Mechanism of toxicity in rotenone models of Parkinson's disease. J Neurosci 2003; 23: 10756-10764.

56. Ekstrand MI, Galter D. The MitoPark Mouse - an animal model of Parkinson's disease with impaired respiratory chain function in dopamine neurons. Parkinsonism Relat Disord 2009; 15: 185-188.

57. Kaur H, Chauhan S, Sandhir R. Protective Effect of Lycopene on Oxidative Stress and Cognitive Decline in Rotenone Induced Model of Parkinson's Disease. Neurochem Res 2011; 36: 1435-1443.

58. Akundi RS, Huang Z, Eason J, Pandya JD, Zhi L, Cass WA, Sullivan PG, Bueler H. Increased mitochondrial calcium sensitivity and abnormal expression of innate immunity genes precede dopaminergic defects in Pink1-deficient mice. PloS One 2011; 6: e16038.

59. Barsoum MJ, Yuan H, Gerencser AA, Liot G, Kushnareva Y, Gräber S, et al. Nitric oxide-induced mitochondrial fission is regulated by dynamin-related GTPases in neurons. EMBO J 2006; 25: 3900-3911.

60. Greenamyre JT, Betarbet R, Sherer TB. The rotenone model of Parkinson's disease: genes, environment and mitochondria. Parkinsonism Relat Disord 2003; 9: 59-64.

61. Tanner CM, Kamel F, Ross GW, Hoppin JA, Goldman SM, Korell M, et al. Rotenone, paraquat, and Parkinson's disease. Environ Health Perspect 2011; 119: 866-872. 
62. Gandhi S, Wood-Kaczmar A, Yao Z, Plun-Favreau H, Daes E, Klupsch K, et al. PINK1-associated Parkinson's disease is caused by neuronal vulnerability to calcium-induced cell death. Mol Cell 2009; 33: 627-638.

63. Heeman B, Van den Haute C, Aelvoet SA, Valscchi F, Rodenburg RJ, Reumers V, et al. Depletion of PINK1 affects mitochondrial metabolism, calcium homeostasis and energy maintenance. J Cell Sci 2011; 124: 1115-1125.

64. Shin JH, Ko HS, Kang H, Lee Y, Lee YI, Pletinkova O, et al. PARIS (ZNF746) repression of PGC-1a contributes to neurodegeneration in Parkinson's disease. Cell 2011; 144: 689-702.

65. Onyango IG, Khan SM, Bennett JP. Mitochondria in the pathophysiology of Alzheimer's and Parkinson's disease. Frontiers in Bioscience 2017; 22: 854-872.

66. Rege SD, Geetha T, Griffin GD, Broderick TL, Babu JR. Neuroprotective effects of resveratrol in Alzheimer disease pathology. Front Aging Neurosci 2014; 11: 218.

67. Braidy N, Judger BE, Poljak A, Jayasena T, Mansour H, Navabi SM, Sachdev P, Grant R. Resveratrol as a Potential Therapeutic Candidate for the Treatment and Management of Alzheimer's Disease. Curr Top Med Chem 2016; 16: 1951-1960.

68. Jia Y, Wang N, Liu X. Resveratrol and Amyloid-Beta: Mechanistic Insights. Nutrients 2017; 9: 1122.

69. Jang JH, Surh YJ. Protective effect of resveratrol on $\beta$-amyloid-induced oxidative PC12 cell death. Free Radic Biol Med 2003; 34: 1100-1110.

70. Calabrese V, Cornelius C, Mancuso C, Pennisi G, Calafato S, Bellia F, et al. Cellular Stress Response: A Novel Target for Chemoprevention and Nutritional Neuroprotection in Aging, Neurodegenerative Disorders and Longevity. Neurochem Res 2008; 33: 2444-2471.

71. Penalver P, Belmonte-Reche E, Adan N, Caro M, Mateos-Martin ML, Delgado M, Gonzalez-Rey E, Morales JC. Alkylated resveratrol prodrugs and metabolites as potential therapeutics for neurodegenerative diseases. Eur J Med Chem 2018; 146: 123-138.

72. Chaturvedi RK, Beal MF. Mitochondria targeted therapeutic approaches in Parkinson's and Huntington's diseases. Mol Cell Neurosci 2013; 55: 101-114.

73. Beal MF. Neuroprotective effects of creatine. Amino Acids 2011; 40: 1305-1313.

74. N.E.T.i.P.D.I. Writing Group for the, Kieburtz K, Tilley BC, Elm JJ, Babcock D, Hauser R, Ross GW, et al. Effect of creatine monohydrate on clinical progression in patients with Parkinson disease: a randomized clinical trial. JAMA 2015; 313: 584-593.

75. Yang L, Calingasan NY, Wille EJ, Cormier K, Smith K, Ferrante RJ, Beal MF. Combination therapy with coenzyme Q10 and creatine produces additive neuroprotective effects in models of Parkinson's and Huntington's diseases. J Neurochem 2009; 109: 1427-1439.

76. Kaidery NA, Thomas B. Current perspective of mitochondrial biology in Parkinson's disease. Neurochemistry International 2018; 117: 91-113.

77. East DA, Fagiani F, Crosby J, Georgakopoulos ND, Bertrand H, Schaap M, et al. PMI: a DeltaPsim independent pharmacological regulator of mitophagy. Chem Biol 2014; 21: 1585-1596. 